\title{
KEDUDUKAN HUKUM WAKAF TUNAI DALAM TELAAH FIQH MUAMALAH SERTA IMPLEMENTASINYA DALAM HUKUM POSITIF DI INDONESIA
}

\author{
Naimah \\ Fakultas Syari'ah dan Ekonomi Islam IAIN Antasari, Jl. Jendral Ahmad Yani Km 4,5 Banjarmasin
}

\begin{abstract}
The issue of cash waqf is not really a new case in the study of fiqh. Historically, cash waqf basically included in the kbilafiyah. The legal disagreement occurs as a result of culture and understanding of the legal community is still struggling in the region of fixed asset waqf. There are several answers as well as a legal opinion to be used as proof to some madzhabscholars, one of which is the opinion of Imam Hanafi that allow cash as waqf endowments on the basis of Istibsan bi al-'Urfi.The basic argument of the Hanafi is the hadeeth narrated by Abdullah bin Mas'ud, may Allah be pleased. While, Imam Malik also allow the base diwakafkan quality goods. Beside those arguments, Imam Shafi'i does not allow cash waqf and argue that the cash waqf does not immortal (can disappear). Theseare the law of several fuqaha answers to this problem. While in Indonesia, legally justify the cash waqf with the issuance of Undang-Undang No. 41 Tahun 2004 about Endowments and Peraturan Pemerintah (Government Regulation)No. 42 Tahun 2006 about The Implementation of Undang-Undang No. 41 Tahun2004 which the Regulation Legislation can provide legal certainty on the application and implementation cash waqf in Indonesia.

Abstrak :Isu mengenai wakaf tunai sesungguhnya bukanlah perkara baru dalam kajian fiqh. Dalam sejarahnya, wakaf tunai pada dasarnya masuk dalam wilayah khilafiyah. Terjadi silang pendapat hukum tersebut akibat kultur dan pemahaman hukum masyarakat masih bergelut dalam wilayah wakaf tidak bergerak.Ada beberapa jawaban serta pendapat hukum untuk dijadikan hujjah sebagian ulama madzhab, salah satunya ialah pendapatImamHanafi yang membolehkan wakaf tunai sebagai wakaf atas dasar Istibsan bi al-'Urfi. Dasar argumentasi mazhab Hanafi adalah hadits yang diriwayatkan oleh Abdullah bin Mas'ud, ra.Sedangkan Imam Malik juga membolehkan dengan dasar kualitas barang yang diwakafkan. Sementara Imam Syafi'i tidak membolehkan wakaf tunai, dengan alasan bahwa wakaf tunai tidak abadi (bisa lenyap).Inilah yang menjadi jawaban hukum dari Fuqahaterhadap permasalahan ini. Sementara di Indonesia, secara yuridis membenarkan adanya wakaf tunai dengan terbitnya Undang-Undang No. 41 tahun 2004 Tentang Wakaf dan Peraturan Pemerintah Nomor 42 Tahun 2006 Tentang Pelaksanaan Undang-Undang 41 tahun2004 yang mana Peraturan Perundang-Undangan ini dapat memberikan kepastian hukum tentang penerapan dan pelaksanaan wakaf tunai di Indonesia.
\end{abstract}

Kata kunci: WakafTunai,Fiqh Muamalah, Hukum Positif

\section{Pendahuluan}

Wakaf adalah suatu perbuatan hukum yang sangat diajurkan yang sudah disepakati para pakar hukum Islam, karena wakaf telah mendapat perhatian dikalangan para para pakar hukum Islam,meskipun sifatnya yang bersifatijtihadi tetapi keberadaannya cukup di perhatikan oleh para ahliahli fiqh, disebabkan banyaknya manfaat dari adanya wakaf. Banyak mengalami dinamika dinamika yang berkaitan erat dengan kondisi dan keadaan .
Wakaf merupakan sarana yang secara legalitas formil baik itu hukum Islam maupun Hukum Positif dapat dipahami sebagai lembaga keagamaan yang sangat penting, di samping sebagai lembaga keislaman lainnya seperti zakat, infak dan shadakah. Institusi wakaf yang dikenal dikalangan umat Islam berasal dari bahasa Arab, waqf dari kata kerja waqafa yang berarti menghentikan, berdiam di tempat atau menahan sesuatu, Sinonim waqf adalah habs, artinya 
menghentikan atau menahan. Bentuk jamak waqf adalah awqaf dan bentuk jamak habs adalah abbas. ${ }^{1}$

Dengan adanya Wakaf, ini dapat memudahkan umat Islam untuk selalu melakukan taqarrub (mendekatkan)diri pada Allah SWT. Pada dasarnya makna subtansi wakaf juga sangat besar bagi perkembangan sosial dan ekonomi bagi masyarakat. Maka dari itu, Islam meletakkan amalan wakaf sebagai salah satu ibadah besar manfaatnya dan juga sangat menggembirakan. ${ }^{2}$

Al-Qu'an dan As-Sunnah sebagai sumber hukum Islam memuat pernyataan-pernyataan umum aturan mengenai perkara-perkara yang sifatnya muamalah. Adapun mengenai pengaturan yang menyangkut hukum syar'iah praktis harus digali dari sumber asli al-Qur'an dan as-Sunnah itu sendiri melalui metode yang dikenal dengan sebutan metode ijtihad dengan ketentuan yang telah disepakati oleh para ulama terdahulu. Nasnas di dalam al-Qur'an dan as-Sunnah yang murni merupakan wahyu Allah SWT disebut dengan

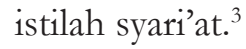

Syariat pada dasarnya janganlah sampai dicampuri oleh daya pikir yang memiliki sifat yang khusus dan tetap, tidak dapat berubah dan tidak dapat diubah sepanjang masa. ${ }^{4} \mathrm{Di}$ sisi lain, permasalahan perkara manusia yang sifatnya muamalah terus berkembang seiring dengan dinamika zaman yang tentunya tidak memuat secara khusus dalam nass, dan hanya dijelaskan secara umum. Agar pendapat hukum para Fuqaha tidak bertentangan dengan apa yang sudah ada ketentuanya secara khusus diatur dalam Qur'an dan Hadits Rasulullah, maka harus melakukan upaya penggalian dan pemahaman hukum secara mendalam terhadap al Qur'an dan as-Sunnah. Sesuai dengan sabda nabi SAW kepada Mu'âdh bin Jabal, apabila tidak menemukan suatu ketetapan hukum di dalam al-Qur'an dan as-Sunnah maka umat Islam diberi solusi untuk melakukan ijtihad dengan metodologi yang telah ditetapkan dan disepakati ulama. Hasil-hasil ijtihad para ulama merupakan hukum-hukum syar'iah praktis yang dihasilkan dari dalil-dalil terperinci yang kemudian

\footnotetext{
1 Moh. Daud Ali, Sistem Ekonomi Islam Zakat dan Wakaf, (Jakarta: UI Press, 1988), hlm. 80.

2 Ahmad Azhar Basyir, Hukum Islam Tentang Wakaf, Ijarah dan Syirkah, (Bandung: PT. Al-Ma'arif, 1987), hlm 7.

3 Muh. Zuhri, Hukum Islam Dalam Lintasan Sejarah(Jakarta: PT.Raja Grafindo Persada,1996), hlm. 2.

4 Ibid
}

disebut dengan fiqih. ${ }^{5}$ Dengan demikian karakteristik fiqih adalah fleksibel dan dapat berubah sesuai dengan kondisi manusia yang dipengaruhi oleh tempat, masa dan tingkat intelektual mujtahid itu sendiri. ${ }^{6}$

Dalam bidang fiqih wakaf, salah satu perbedaan pendapat di kalangan para pakar hukum Islam adalah mengenai masalah wakaf tunai. Dikalangan para Fuqaha klasik, hukum wakaf tunai masih masuk dalam wilayah khilafiyah. Perbedaan pendapat hukum tersebut diakibatkan kultur dimasyarakat yang masih bergelut diwilayah wakaf tidak bergerak. Di kalangan Malikiyah popular pendapat yang membolehkan berwakaf dalam bentuk uang kontan seperti di lihat dalam kitab alMajmu' oleh Imam Nawawi yang mengatakan:"dan para sahabat kita berbeda pendapat tentang wakaf dengan dirham dan dinar. "Dan orang yang membolehkan mempersewakan dirham dan dinar membolehkan berwakaf dengannya dan yang tidak membolehkan mempersewakannya tidak membolehkan mewakafkannya"7 .

Wahbah Zuhaili menyatakan bahwa mazhab Maliki membolehkan wakaf makanan, uang dan benda bergerak lainnya. ${ }^{8}$ Syeikhul Islam Ibnu Taimiyah dalam Al-Fatwa, meriwayatkan satu pendapat dari kalangan Hanabilah yang membolehkan berwakaf dalam bentuk uang, ${ }^{9} \mathrm{http}: /$ /aqfa.blogspot.com/2010/05/wakaf-tunai.html _ftn6

Di Indonesia,secara yuridis formil UndangUndang Nomor 41 tahun 2004 Tentang Wakaf, menentukan bahwa benda yang dapat diwakafkan tidak saja benda tetap (tidak bergerak) tetapi terdiri dari benda bergerak dan tidak bergerak. Di antara benda yang bergerak yang dapat diwakafkan adalah wakaf tunai (wakaf uang).

\footnotetext{
5 Muhammad Abu Zahrah, Ushul Fiqih, terj. Saefullah Ma'sum, et.al. (Jakarta: Pustaka Firdaus, 2005), hlm. 2 Ibid, hlm. 567

7 Biro Perbankan Syari'ah BI 2001, Peranan Perbankan Syariah dalam Wakaf Tunai (Sebuah Kajian Konseptual)' dalam WAKAF TUNAI Inovasi Finansial Islam, Jakarta: PSTTI-UI,2006), hlm.99.

8 Pedoman Pengelolaan dan Pengembangan Wakaf, (Jakarta : Depag RI,2006), hlm,.44.

9 Biro Perbankan Syari'ah BI 2001, Op.cit, hlm.99.
} 
MUI (Majlis Ulama' Indonesia) memperbolehkan wakaf tunai/uang melelui fatwa MUI pada tanggal 11 Mei 2002. Isi fatwa MUI tersebut sebagai berikut : ${ }^{10}$

1. Wakaf uang (cash wakaf/ waqf al-nuqud) adalah wakaf yang dilakukan seseorang, kelompok orang, lenmbaga atau badan hukum dalam bentuk uang tunai.

2. Termasuk ke dalam pengertian uang adalah surat-surat berharga.

3. Wakaf uang hukumnya jawaz (boleh)

4. Wakaf uang hanya boleh disalurkan dan digunakan untuk hal-hal yang dibolehkan secara syariah. Nilai pokok wakaf uang harus dijamin kelestariannya, tidak boleh dijual, dihibahkan dan atau diwariskan.

Wakaf tunai penting sekali dikembangkan di negara-negara yang kondisi perekonomiannya kurang baik sebagaimana negara Indonesia, karena berdasarkan pengalaman di berbagai negara hasil investasi wakaf uang dapat dipergunakan untuk menyelesaikan masalah-masalah sosial yang terjadi di negara yang bersangkuatan. Oleh karena itu dalam Undang-Undang Nomor 41 Tahun 2004 Pasal 16 ayat (1) disebutkan bahwa harta benda wakaf terdiri atas benda tidak bergerak dan benda bergerak. ${ }^{11}$

\section{Pengertian Wakaf Tunai}

Hukum Wakaf Tunai adalah sebuah pengaturan benda bergerak yang tujuannya untuk kepentingan pendidikan, riset, rumah sakit, pemberdayaan ekonomi lemah dan lain-lain. ${ }^{12}$ Sedangkan menurut ketetapan fatwa MUI tentang wakaf tunai yang dimaksud dengan waqaf tunai atau waqf al-Nuqud adalah "wakaf yang dilakukan seseorang, kelompok orang atau Lembaga dan badan hukum dalam bentuk uang tunai". ${ }^{13}$ Konsep hukum wakaf tunai dapat diinfakkan dalam bentuk

${ }^{10}$ Keputusan fatwa MUI(tentang wakaf uang) pada tanggal 11 Mei 2002.

11 Departemen Agama RI, Undang-Undang Nomor 41 Tabun 2004 Tentang Wakaf dan Peraturan Pemerintah Nomor 42 Tabun 2006 tentang Pelaksanaannya, (Jakarta: Direktorat Jenderal Bimbingan Masyarakat Islam, 2007), hlm. 11.

12 Depag RI Stategi Pengembangan Waqaf Tunai di Indonesia, (Jakarta : Direktorat Jendral Bimbingan Masyarakat Islam, 2007), hlm. 8.

${ }^{13}$ Depag RI,Paradigma Baru Waqaf di Indonesia, (Jakarta : Direktorat Jendral Bimbingan Masyarakat Islam, 2007), hlm. 137. uang tunai, harta yang berupa modal financial yang disimpan di bank-bank atau lembaga keuangan, atau berupa saham perusahaan yang hasilnya dapat dipergunakan untuk kemaslahatan umat. ${ }^{14}$

\section{Dasar Hukum Wakaf Tunai}

Sistem wakaf merupakan konsep yang tidak secara jelas dan tegas disebutkan dalam al-Qur'an. Bebeda dengan zakat yang secara tegas disebutkan dalam al-Qur'an.Kendatipun demikian, dalam beberapa ayat yang memerintahkan manusia untuk berbuat baik untuk kebaikan masyarakat, dipandang oleh para ahli hukum sebagai landasan perwakafan. ${ }^{15}$ Pemahaman masyarakat ialah tentang dasar hukum wakaf yang selama ini hanya dipahami sebagai benda yang tetap atau tidak bergerak.Para ahli fiqh menjelaskan beberapa ayat yang sifatnya umum. Adapun dasar hukum wakaf tunai, yaitu

1. Firman Allah dalam surat al-Hajj ayat 77 yang artinya "Perbuatlah kebajikan, supaya kamu mendapatkan kemenangan."

2. Firman Allah dalam Surat Ali Imran ayat 92 yang artinya "Kamu Sekali-kali tidak sampai kepada kebajikan (yang sempurna), sebelum kamu menafkabkan sebagaian barta yang kamu cintai. Dan apa saja yang kamu nafkabkan, maka sesunggubnya Allah mengetabuinya."

3. Firman Allah dalam Surat Al-Baqarah ayat 261 yang artinya "Perumpamaan (Nafkeah yang dikeluarkan oleb) Orang yang menafkabkan hartanya di jalan Allah adalah serupa dengan benih yang menumbubkean tujuh butri, pada setiap butirbutir seratus biji allah melipatgandakan (ganjaran) bagi siapa yang dia kehendaki dan Allab Maha Luas (Karunia-Nya) lagi Maha Mengetabui).

4. Hadist Nabi Muhammad SAW:

$$
\text { ادو قطع عمله الا من ثلاث صدقة جارية او علم ينتفع به }
$$

"Dari Abu Hurairah ra, Sesungguhnya Rasulullah SAW, bersabda; Apabila anak adam Manusia meninggal dunia, maka putuslah amalnya, kecuali tiga perkara yaitu shadaqah jariah, ilmu yang bermanfaat dan anak sholeh yang mendoakan orang tuanya". (H.R Muslim).

\footnotetext{
${ }^{14}$ Achmad Djunaidi dan Thobieb Al-Asyhar, Menuju Era Wakaf Produktif, (Depok : Mumtaz Publishing, 2007), hlm. 71-72.

15 Mohammad Daud Ali, Loc.cit
} 
Para ulama menafsirkan kata-kata shadaqah jariyah yang akan terus mengalir pahalanya dalam hadist tersebut dengan wakaf. Nash nash diatas merupakan nash yang jelas yang secara khusus dijadikan landasan utama adanya syari'ah wakaf. ${ }^{16}$

Hadist Nabi Muhammad SAW:

"Diriwayatkan dari Ibnu Umar ra, ia berkata kepada Nabi Muhammad SAW, saya mempunyai seratus saham di khaibar, belum pernah saya mendapatkan harta yang lebih saya kagumi melebihi itu, saya bermaksud menyedekah kannya. Nabi SAW berkata :Tahanlah pokoknya dan sedekahkan buahnya pada sabililah." (H.R An Nasa'i).

Adapun dikalangan Ulama, Imam Az Zuhri (wafat tahun $124 \mathrm{H}$ ) memberikan pendapat hukum yang membolehkan wakaf diberikan dalam bentuk uang, yang saat itu berupa dinar dan dirham, untuk pembangunan sarana dakwah, sosial dan pembangunan umat. Ulama Mazhab Hanafiyah membolehkan wakaf uang, dan sebagian ulama syafi'iyah membolehkan wakaf uang (dinar dan dirham). ${ }^{17}$

Komisi Fatwa Majelis Ulama Indonesia (MUI) juga membolehkan wakaf uang. Fatwa komisi fatwa MUI itu dikeluarkan pada tanggal 11 Mei 2002. Pada saat itu komisi fatwa MUI juga merumuskan definisi tentang wakaf, yaitu:

$$
\text { حصبس مال يمكن الإنقطاع به مع بقاء عينه بقطع فن رقبته }
$$

"Menekan harta yang dapat dimanfaatkan tanpa lenyap bendanya atau pokonya. Dengan cara tidak melakukan tindakan hukum terhadap benda tersebut (menjual, memberikan, atau mewariskan nya), untuk disalurkan (hasilnya) pada sesuatu yang mubah (tidak) haram yang ada".

Secara hukum positif di Indonesia wakaf tunai telah diatur juga dalam undang undang wakaf nomor 41 tahun 2004 dalam pasal 16 ayat 1 dan 3 yang berbunyi sebagai berikut :

\footnotetext{
${ }^{16}$ Didin Hafidhuddin, M. Sc, Wakaf Uang Dalam Pandangan Syariat Islam, Kumpulan Hasil Seminar Perwakafan, (Jakarta: Bimas dan Haji DEPAG RI, Jakarta, 2004), hlm. 194.

${ }^{17}$ Huswatun Hasanah, Strategi Pengelolaan Wakaf Dalam Meningkatkan Kesejabteraan Umat, Kumpulan Hasil Seminar Perwakafan, (Jakarta: Bimas dan Haji DEPAG RI, 2004), hlm.. 124.
}

\section{Pasal 16}

1. Harta benda wakaf terdiri dari:

- benda tidak bergerak; dan

- benda bergerak.

2. Benda bergerak sebagaimana dimaksud pada ayat (1) huruf b adalah harta benda yang tidak bisa habis karena dikonsumsi, meliputi:

- uang;

- logam mulia;

- surat berharga;

- kendaraan;

- hak atas kekayaan intelektual;

- hak sewa; dan benda bergerak lain sesuai dengan ketentuan syariah dan peraturan perundang.undangan yang berlaku.

Dengan demikian jelas bagi kita tentang dasar hukum wakaf tunai, baik secara hukum Islam maupun hukum positif yang ada di Indonesia.

\section{Manfaat Wakaf Tunai}

Menurut Umer Chapra dalam bukunya, The Tuture of Oconimics, mengungkapkan bahwa sejumlah nilai dan institusi Islam dianggap dapat membantu menciptakan persaudaraan Islam yang ideal, persamaan sosial dan distribusi yang merata. Sebagai salah satu institusi keagamaan yang erat hubungannya dengan sosial ekonomi yang tidak melihat lintas waktu, wakaf ternyata tidak hanya sekedar mentransformasikan tabungan masyarakat berkecukupan menjadi dana umat, namun juga dapat menjadi salah satu sarana meratakan pertumbuhan ekonomi suatu negara. ${ }^{18}$

Adapun manfaat wakaf tunai yang diutarakan M. Syafei Antonio ada empat, yaitu: ${ }^{19}$

1. Seseorang yang memiliki dana terbatas sudah bisa mulai memberikan dana wakafnya tanpa harus menunggu menjadi tuan tanah terlebih dahulu.

2. Melalui wakaf uang, aset-aset wakaf yang berupa tanah-tanah kosong bisa mulai dimanfaatkan dengan pembangunan gedung atau diolah untuk lahan pertanian, serta juga bisa membantu sebagian lembaga-lembaga pendidikan Islam.

\footnotetext{
${ }^{18}$ Ibid, hlm. 124.
}

${ }^{19}$ M. Syafii Antonio, Cash Waaf Dan Anggaran Pendidikan, (Jakarta: Kumpulan Hasil Seminar Perwakafan, Bimas dan Haji DEPAG RI, 2004), hlm. 212. 


\section{Akar Historis Perkembangan Wakaf Tunai}

Dalam Kajian Sejarah, wakaf merupakan lembaga keagamaan yang paling tua dalam Islam dan bahkan sudah dikenal sejak zaman Nabi Saw. ${ }^{20}$ Dalam sejarah pembinaan Hukum Islam, awal wakaf telah dikenal semenjak masa rasul, walaupun pada saat itu belum menggunakan term tersebut. Selanjutnya para ulama berbeda pendapat mengenai siapa orang pertama yang melaksanakan pratik wakaf. Sebagian mereka adalah ada yang mengatakan bahwa Nabi Muhammad adalah orang yang pertama kali melaksananakan praktik wakaf, sedangkan ulama yang lain adalah mengatakan Umar Bin Khattab. Perselisihan pendapat ini terkait dengan persoalan wakaf produktif yang dipraktikkan Nabi Muhammad berupa tujuh lokasi perkebunan pohon kurma yang sangat terkenal, yaitu al-a'raf, ash-shafiyah, ad-dalal, al-misyab, alhusna, dan masyrabah ummi Ibrahim dengan wakaf yang dipraktikkan Umar di Khaibar. ${ }^{21}$

Para ahli hukum Islam, menyebutkan bahwa wakaf yang pertama adalah bangunan suci Ka'bah di Makkah. Dalam QS. Ali Imran (3) ayat 96 bangunan suci tersebut dikenal sebagai rumah ibadah pertama yang dibangun oleh umat manusia. Sejarah mencatat, wakaf keagamaan pertama terjadi pada masa Rasulullah Saw., Ketika hijrah bersama kaum Muhajirin ke Madinah, Rasulullah beserta kaum muslimin membangun Masjid Quba. Inilah wakaf keagamaan pertama yang terjadi dalam sejarah Islam. Enam bulan setelah membangun Masjid Quba, di pusat Kota Madinah juga dibangun Masjid Nabawi, yang juga dalam bentuk wakaf keagamaan. ${ }^{22}$

Pada zaman Nabi Muhammad Saw ada Seseorang bernama Mukhairiq mendermakan (mewakafkan) tujuh bidang kebun buah-buahan miliknya yang ada di Madinah setelah dia meninggal kepada Nabi Saw, pada 626 M. Nabi Saw, mengambil alih kepemilikan tujuh bidang kebun tersebut dan menetapkannya sebagai wakaf derma untuk diambil manfaatnya bagi fakir miskin. Praktik

\footnotetext{
20 Syamsul Anwar, Studi Hukum Islam Kontemporer, (ed.) M. Muchlas Rowie, (Jakarta: Rm Books, 2007), hlm. 83.

${ }^{21}$ Mukhlisin Muzarie, Fiqh Wakaf, Syarofin Arba MF (ed.), (Yogyakarta: Dinamika, 2010), hlm. 43.

22 John L. Esposito, dalam Ensiklopedi-Oxford Dunia Islam Modern, dan diterjemahkan dari The Oxford Encyclopedia Of the Modern Islamic Word. terj. Eva Y.N. Femmy S., Jarot W., Poerwanto, Rofiq S., Jilisd ke-2, (Jakarta: 2001, Mizan), hlm. 120.
}

itu kemudian diikuti oleh para sahabat Nabi Saw, dan Khalifah Umar bin Khattab. Tak lama setelah Nabi Saw., wafat, Khalifah Umar bin Khattab memutuskan untuk membuat dokumen tertulis mengenai wakafnya di Khaibar. Dia mengundang beberapa sahabat untuk menyaksikan penulisan dokumen tersebut. Wakaf itu kemudian dikenal sebagai wakaf keluarga (al-waqf al-abli). Penyerahan tanah oleh Umar yang terletak di Khaibar untuk kepentingan umum kaum muslimin juga dianggap sebagai bentuk wakaf tertua yang berasal dari zaman Nabi Saw. ${ }^{23}$

Pada Abad kedua Hijriah, umat Islam mulai mengenal istilah wakaf tunai. Imam az - Zuhri merupakan salah seorang Ulama terkemuka dan peletak dasar kodifikasi al-hadis yang berpendapat hukum bolehnya wakaf dinar dan dirham untuk pembangunan sarana dakwah, sosial, dan pendidikan umat Islam. Perkembangan wakaf tunai terjadi pada masa kepemimpinan Salahudin alAyyubi,di Mesir, hasil dari wakaf tunai digunakan untuk membiayai pembangunan negara serta membangun masjid, sekolah, rumah sakit. Pada masa Bani Umayyah, wakaf terus berkembang khususnya di Syam dan Mesir, serta dunia Islam lainnya. Di Mesir bahkan sudah ada badan pengurus khusus tentang harta wakaf yang dipelopori oleh Hakim Tauban Ibnu Namir. ${ }^{24}$

Di Indonesia wakaf telah lama dikenal masyarakat, walaupun hanya dilakukan oleh sebagian kecil masyarakat, pemberian dana wakaf biasanya hanya dilakukan oleh orang-orang mempunyai harta kekayaan yang cukup besar dan umumnya diberikan dalam bentuk harta tak bergerak. Sedangkan wakaf untuk harta bergerak belum begitu banyak dikenal oleh masyarakat Indonesia. Perbincangan pengelolaan wakaf yang dilakukan secara profesional mulai menggeliat lagi di Indonesia setelah terjadi letupan interaksi dengan gagasan wakaf Tunai yang digulirkan oleh tokoh Ekonomi asal Banglades, yaitu Prof. M. A. Mannan, yang pada akhirnya muncul kreasi baru gagasan wakaf investasi, yang di Indonesia sudah dimulai oleh Dompet Dhuafa Republika yang bekerjasama dengan Batasa (BTS) Capital dengan Program Dompet Du'afanya, PB. Matla'ul Anwar dengan Program Dana Firdaus nya, dan Bank

\footnotetext{
23 Syamsul Anwar, Op.cit, hlm. 84.

${ }^{24}$ Ibid, hlm. 83.
} 
Mu'amalat Indonesia (BMI) dengan Institusi barunya Baitul Mal Mu'amalat. ${ }^{25}$

Wakaf tunai bagi umat Islam Indonesia memang relatif baru. Hal ini bisa dilihat dari peraturan yang melandasinya. Majelis Ulama' Indonesia (MUI) baru memberikan fatwanya pada tanggal 28 Shafar 1423 H / 11 Mei 2002 M, yang ditandatangani oleh KH. Ma'ruf Amin sebagai ketua Komisi Fatwa dan Drs. Hasanudin, M.Ag. sebagai sekretaris komisi. Fatwa MUI tersebut merupakan upaya MUI dalam memberikan pengertian dan pemahaman umat Islam bahwa wakaf uang dapat menjadi alternative untuk berwakaf. Lebih-lebih uang merupakan variable penting dalam pembangunan ekonomi masyarakat. Sedangkan undang-undang wakaf disahkan pada tanggal 27 oktober 2004 oleh presiden Susilo Bambang Yudhoyono. ${ }^{26}$

Meski terlambat dibanding sejumlah negara lain, kesadaran untuk berwakaf secara lebih produktif telah muncul pada sebagian masyarakat Indonesia. Berbagai seminar, workshop dan pelatihan diselenggarakan untuk merumuskan cara terbaik menghimpun dan memanfaatkan dana wakaf yang berpotensi dihimpun dalam jumlah besar. Wakaf produktif bias juga dilakukan dengan memanfaatkan ribuan hektar tanah wakaf yang tersebar diseluruh Tanah Air untuk kegiatankegiatan ekonomi bernilai tinggi. ${ }^{27}$

\section{Wakaf Tunai dalam Kajian Hukum Islam (Fiqh Muamalah)}

Secara umum, hukum wakaf menurut ijtihad para imam mazhab adalah sunnah dan bertujuan untuk kemaslahatan ummat, misalnya untuk pembangunan yang bersifat keagamaan baik pembangunan fisik maupun non fisik. Sebagaimana dikemukakan dalam tulisan-tulisan terdahulu, bahwa tidak ada satu ayat Al-Qur'an dan $\mathrm{Al}$-Hadis yang menjelaskan wakaf secara khusus. Kalaupun ada ayat Al-Qur'an Al -Hadis hanya ditafsirkan oleh para ulama pengertiannya adalah

${ }^{25}$ Direktorat Jenderal Bimbingan Masyarakat Islam dan Penyelenggaraan Haji, Loc.cit.

${ }^{26}$ Departemen Agama RI, Strategi Pengembangan Wakaf Tunai di Indonesia, (Jakarta: Direktorat Pemberdayaan Wakaf dan Direktorat Jenderal Bimbingan Masyarakat Islam, 2006), hlm. 8

${ }^{27}$ M. Sholahuddin, Lembaga Ekonomi dan Kenangan Islam, (Surakarta: Muhammadiyah University Press, 2006), hlm. 197. wakaf. Lazimnya, sumber hukum lain yang digunakan para ahli fiqh sebagai dasar hukum wakaf adalah Ijtihad Ulama.

Permasalahan wakaf, khususnya wakaf tunai merupakan perkara muamalah. Oleh sebab itu bolehnya masuk pemikiran-pemikiran manusia sebagai proses pemahaman terhadap Qur'an dan Hadits yang hanya memuat secara umum dan itu masih diperbolehkan selagi tidak bertentangan.

Mazhab Hanafi merupakan aliran fiqh yang merupakan hasil ijtihad Imam Abu Hanifah, mazhab ini banyak menggunakan ra'yu atau hasil fikiran. Mazhab ini bermula di Irak. Saat itu Irak merupakan tempat pengembangan fiqh aliran ra'yu yang berakar dari masa sahabat Abdullah bin Mas'ud dikirim bin untuk guru qadhi (hakim) di Kufah, Irak, dengan membawa faham fiqh Umar. Sedangkan Umar bin Khattab terkenal sebagai ahli hukum Islam yang hasil ijtihad-nya banyak menggunakan tujuan hukum dengan memahami ayat atau hadis secara rasional. Metode Ijtihad yang mempengaruhi mazhab ini adalah qiyas (analogi), istibsan, 'urf dan biyal syar'iyyah. ${ }^{28}$

Di kalangan masyarakat muslim, khususnya di Indonesia wakaf tunai masih difahami kurang proporsional. Pemahaman tersebut tentunya tidak lepas dari berbagai pengaruh imam madzab. ${ }^{29}$ Imam Syafi'i, misalnya sangat menekankan wakaf pada fixwed asset (harta tetap), sehingga menjadikannya syarat sah wakaf. ${ }^{30}$

Dengan demikian pembahasan harta benda wakaf dalam fiqh klasik Imam Syafi'i seperti dalam kitab al Umm atau bahkan fiqh modern seperti fiqh as-Sunnah Sayyid Sabiq tidak memperbolehkan wakaf tunai/uang, karena dinilai tidak akan kekal ketika dimanfaatkan. Selain itu, alasan lain adalah jika berdasarkan 'Urf (kebiasaan yang berlaku), maka wakaf uang hanya berlaku di wilayah-wilayah tertentu dari bekas wilayah kekaisaran Bizantium (Romawi) saja, di tempat lain tidak berlaku. ${ }^{31}$

Sedangkan Imam Malik mengartikan 'keabadian' lebih pada manfaat barang yang

${ }^{28}$ Wahbah az-Zuhaily, Fiqh al-Islâmî wa Adillatuhî, (Mesir: Dar al-Fikri, 1986), hlm. 153.

29 Tim Direktorat Jenderal Bimbingan Masyarakat Islam dan Penyelenggara Haji Depag RI, sebagaimana dikutip Wadjdy dan Mursyid, dalam Wakaf \& Kesejabteraan Umat: Filantropi Islam yang Hampir Terlupakan, (Yogyakarta:Pustaka Pelajar, 2007), hlm.88.

${ }^{30}$ Ibid

${ }^{31}$ Ibid 
diwakafkan, baik itu asset tetap maupun asset bergerak. Ia memperluas bahasan wakaf mencakup barang-barang bergerak lainnya seperti sapi atau wakaf buah tertentu, begitu pula dengan uang tunai yang bisa digunakan untuk menopang pengelolaan wakaf secara produktif.

Madz̧ hab Hanafi membolehkan wakaf tunai atas dasar Istibsan bi al-Urfi, karena sudah banyak masyarakat yang melakukannya. Mad₹̧hab Hanafi memang berpendapat bahwa hukum yang ditetapkan berdasarkan 'urf (adat kebiasaan) mempunyai kekuatan yang sama dengan hukum yang ditetapkan berdasarkan nash (teks).

Adapun argumentasi hukum madz̧ab Hanafi adalah hadis yang diriwayatkan oleh Abdullah bin Ma'ud, r.a:

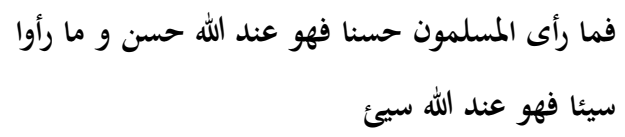

"Apa yang dipandang baik oleh kaum Muslimin, maka dalam pandangan Allah adalah baik, dan apa yang dipandang buruk oleh kaum Muslimin maka dalam pandangan Allah pun buruk".

Adapun alasan ulama yang membolehkan wakaf uang adalah seperti diuraikan dalam kutipan berikut ini: ${ }^{32}$

Dalam kitab al-Is'af fi Abkamil Awqaf, AthTharablis menyatakan:'Sebagian ulama klasik merasa aneh ketika mendengar fatwa yang dikeluarkan oleh Muhammad bin Abdullah AlAnshari, murid dari Zufar, sahabat Abu Hanifah, tentang bolehnya berwakaf dalam bentuk uang kontan, dirham atau dinar, dan dalam bentuk komoditas yang dapat ditimbang atau ditakar, seperti makanan gandum. Yang membuat mereka merasa aneh adalah karena tidak mungkin mempersewakan benda-benda seperti itu, oleh karena itu mereka segera mempersoalkannya dengan mempertanyakan apa yang dapat kita lakukan dengan dana tunai dirham?" Atas pertanyaan ini Muhammad bin Abdullah AlAnshari menjelaskan dengan mengatakan:'Kita investasikan dana itu dengan cara mudharabah dan labanya kita sedekahkan. Kita jual benda makanan itu, harganya kita putar dengan usaha mudharabah, kemudian hasilnya disedekahkan."

Di kalangan Malikiyah populer pendapat yang membolehkan berwakaf dalam bentuk uang

32 Sayyid Sabiq, Fiqih Sunnah, (Jakarta: Pena Pundit Aksara, 2007), hlm. 96. kontan, seperti dilihat dalam kitab Al Majmu' oleh Imam Nawawi yang mengatakan: dan para sahabat kita berbeda pendapat tentang berwakaf dengan dana dirham dan dinar. Orang yang memperbolehkan mempersewakan dirham dan dinar membolehkan berwakaf dengannya dan yang tidak membolehkan mempersewakannya tidak membolehkan mewakafkannya. ${ }^{33}$ Begitu juga Syeikhul Islam Ibnu Taimiyah dalam Al-Fatawa, meriwayatkan satu pendapat dari kalangan Hanabilah yang membolehkan berwakaf dalam bentuk uang, dan hal yang sama dikatakan pula oleh Ibnu Qudamah dalam bukunya al-Mughni. ${ }^{34}$

Komisi Fatwa Majelis Ulama Indonesia (MUI) juga membolehkan wakaf tunai. Fatwa komisi fatwa MUI itu dikeluarkan pada tanggal 11 Mei 2002. Argumentasi didasarkan kepada hadits Ibnu Umar. Pada saat itu, komisi fatwa MUI juga merumuskan definisi (baru) tentang wakaf,yaitu: $:^{35}$

"Menahan harta yang dapat dimanfaatkan tanpa lenyap bendanya atau pokoknya, dengan cara tidak melakukan tindakan bukum terbadap benda tersebut (menjual, memberikan, atau mewariskannya), untuk disalurkan (basilnya) pada sesuatu yang mubah (tidak haram) yang ada."

Apabila memperhatikan definisi wakaf, yang diberikan oleh para pakar hukum Islam, di mana wakaf didefinisikan sebagai menahan bendanya dan memberikan manfaatnya ke arah kebaikan, baik perorangan atau kepentingan umum, dan memperhatikan tata cara mewakafkan dan pengelolaannya, maka ternyata dzat uang wakaf tetap tersimpan di dalam Bank Penerima Wakaf Uang sebagai nadzir. Uang wakaf tersebut dikelola oleh Bank tersebut dengan cara-cara yang dibenarkan oleh syariat. Dari pengelolaan tersebut diperoleh keuntungan. Dan dari keuntungan itu dipergunakan pendanaan atau pembiyaanpembiyaan berbagai keperluan umat Islam. Dari kenyataan tersebut diperoleh kesimpulan, bahwa wakaf tunai telah memenuhi pengertian wakaf dan tujuan dari wakaf secara umum. Karenanya, pendapat-pendapat tentang kebolehan wakaf tunai sebagai diuraikan di atas dapat dipertahankan dan dapat dijadikan pijakan tentang bolehnya Wakaf Tunai

\footnotetext{
${ }^{33}$ Biro Perbankan Syari'ah BI 2001,Op.cit, (Jakarta : PSTTIUI,2006), hlm..99.

${ }^{34}$ Ibid

35 Ibid. hlm. 97.
} 


\section{Wakaf Tunai dalam Kajian Hukum Positif di Indonesia}

Semangat untuk membuat produk peraturan perundang-undangan kegiatan wakaf dalam bentuk Undang-Undang payung hukum terus dilakukan. Akhirnya, pihak Pemerintah Indonesia mengeluarkan Undang-Undang Nomor 41 Tahun 2004 tentang Wakaf dan Peraturan Pemerintah Nomor 42 Tahun 2006 tentang pelaksanaan Undang-Undang Nomor 41 Tahun 2004.

Peraturan perundang-undang tersebut antara lain mengatur bentuk benda wakaf, yaitu benda tetap, dan benda tidak tetap yaitu wakaf tunai. Hal ini dapat dilihat dalam ketentuan yang terdapat dalam Pasal 28 sampai denganpasal 31 UndangUndang Nomor 41 Tahun 2004 dan Pasal 22 sampai dengan pasal 27 Peraturan Pemerintah Nomor 42 Tahun 2006.

Undang-undang Nomor 41 tahun 2004 telah memperluas benda yang dapat diwakafkan oleh wakif, yang dulu sebelum adanya undang-undang ini secara umum hanya terbatas pada benda tidak bergerak atau benda tetap seperti tanah dan bangunan, kini dalam undang-undang tersebut juga diatur mengenai wakaf benda bergerak seperti wakaf tunai (uang). Wakaf Uang dalam Peraturan Menteri Agama Nomor.4 tahun 2009 adalah perbuatan hukum Wakif untuk memisahkan dan/ atau menyerahkan sebagian uang miliknya untuk dimanfaatkan selamanya atau untuk jangka waktu tertentu sesuai dengan kepentingannya guna keperluan ibadah dan/atau kesejahteraan umum menurut syariah.

Dalam pasal 28 Undang-Undang Nomor 41 Tahun 2004 tentang wakaf menjelaskan, bahwa Wakaf benda tidak tetap antara lain berupa uang, dilakukan oleh wakif melalui Lembaga Keuangan Syariah (LKS) yang ditunjuk oleh menteri. Wakaf atas benda tidak tetap berupa uang ini dilaksanakan oleh wakif secara tertulis kepada Lembaga Keuangan Syariah (LKS), kemudian oleh LKS diterbitkan sertifikat wakaf tunai/uang, selanjutnya sertifikat wakaf uang yang telah diterbitkan itu oleh LKS disampaikan kepada wakif dan nazhir sebagai bukti penyerahan harta benda wakaf dan ini tertuang dalam pasal 29 Undang-Undang Nomor 41 tahun 2004. Selanjutnya pasal 30 UndangUndang 41 Tahun 2004 memberikan penjelasan, bahwa Lembaga Keuangan Syariah atas nama nazhir mendaftarkan harta benda wakaf berupa uang tersebut kepada Menteri selambat-lambatnya
7 (tujuh) hari kerja sejak diterbitkannya sertifikat wakaf uang.

Pasal 22 Peraturan Pemerintah Nomor 42 Tahun 2006 memberikan penegasan bahwa wakaf uang yang dapat diwakafkan adalah mata uang rupiah, jika uang yang akan diwakafkan masih dalam mata uang asing seperti Rial, Dolar, Euro, Ringgit Malaysia dan sebagainya, dikonversi terlebih dahulu ke dalam mata uang rupiah.

Secara jelas Peraturan Perundang-undangan di atas memberikan kepastian hukum bahwa wakaf tunai/wakaf uang diakui keberadaannya dalam hukum positif di Indonesia. Di samping itu, dalam Undang-undang wakaf juga diperintahkan pembentukan Badan Wakaf Indonesia (BWI) yang bertugas memajukan dan mengembangkan perwakafan nasional, badan ini merupakan lembaga yang independen. Dalam Undang-Undang 41 Tahun 2004 tentang Wakaf, keanggotaan BWI diangkat dan diberhentikan oleh Presiden. Sedangkan pertanggungjawaban pelaksanaan tugas dilakukan oleh lembaga audit independen dan disampaikan kepada Menteri serta diumukan kepada masyarakat luas.

Adapun Wakaf tunai dalam Undang-undang nomor 41 tahun 2004 diatur dalam pasal 28 sampai pasal 31, yakni:

Pasal 28:

Wakif dapat mewakafkan benda bergerak berupa uang melalui lembaga keuangan syariah yang ditunjuk oleh menteri.

Dari pasal 28 dapat ditarik kesimpulan:

1. Legalitas wakaf tunai sangat jelas dan tidak perlu diperselisihkan lagi.

2. Pengelolaan wakaf uang melalui lembaga keuangan syari'ah.

3. LKS ditunjuk oleh Menteri

Pasal 29:

1. Wakaf benda bergerak berupa uang sebagaimana pasal 28 dilaksanakan oleh wakif dengan pernyataan kehendak Wakif dilakukan secara tertulis

2. Wakaf benda bergerak berupa uang sebagaimana dimaksud dalam pasal 1 diterbitkan dalam bentuk sertifikeat wak af nang. 
3. Setrtifikat wakaf uang sebagaimana dimaksud dalam pada ayat 2 diterbitkean dan disampaikan oleh lembaga keuangan syariah kepada Wakif dan Nazhir sebagai bukti penyeraban harta benda wakaf.

Pasal 30:

Lembaga keuangan Syariah atas nama nazhir mendaftarkan harta benda wakaf berupa uang kepada menteri selambat-lambatnya 7 (tujub) bari sejak. diterbitkannya sertifikat wakaf nang.

\section{Pasal 31:}

Ketentuan lebih lanjut mengenai wakeaf benda bergerak berupa uang sebagaimana dimaksud pasal 28, 29, dan 30 diatur dalam peraturan pemerintah.

Sedangkan mengenai pengelolaan wakaf uang, dalam Pasal 48 Peraturan Pemerintah Nomor 42 tahun 2006 tentang pelaksanaan UndangUndangNomor 41Tahun 2004 tentang Wakaf telah menjelaskan sebagai berikut:

1) Pengelolaan dan pengembangan harta benda wakaf harus berpedoman pada peraturan BWI;

2) Pengelolaan dan pengembangan atas harta benda wakaf uang hanya dapat dilakukan melalui investasi pada produk-produk. LKS dan/atau instrumen keuangan syariab;

3) Dalam hal LKS-PWU menerima wakaf uang untuk. jangka waktu tertentu, naz̧ir hanya dapat melakukan pengelolaan dan pengembangan harta benda wakaf uang pada LKS-PWU dimaksud

4) Pengelolaan dan pengembangan atas harta benda wakaf uang yang dilakukan pada bank syariah harus mengikuti program lembaga penjamin simpanan sesuai dengan peraturan perundangundangan

5) Pengelolaan dan pengembangan atas harta benda wakaf uangyang dilakukan dalam bentuk investasi di luar bank syariah harus diasuransikan pada asuransi syariah. ${ }^{36}$

Dilihat dari penjelasan, dapat ditarik kesimpulan bahwa secara yuridis membenarkan adanya wakaf tunai dan kianya umat Islam di Indonesia dapat memberikan perhatian yang sangat besar untuk memaksimalkan wakaf tunai dan ini sudahlah jelas bahwa kedudukan hukum wakaf tunai sangat kuat untuk dilaksanakan.

${ }^{36}$ http://ekisopini.blogspot.com

\section{Kesimpulan}

Permasalahan hukum wakaf tunai merupakan perkara muamalah. Oleh sebab itu diperlukan pendapat hukum dari para ahli fiqh untuk melakukan proses pemahaman terhadap Qur'an dan Hadits yang hanya memuat secara umum. Dalam bidang fiqih muamalah, hukum wakaf tunai masih masuk dalam wilayah khilafiyah (debateble). Perbedaan pendapat hukum dari para ulama tersebut diakibatkan kultur dimasyarakat yang masih bergelut diwilayah wakaf tidak bergerak. Madzhab Hanafi dan malikiyah membolehkan wakaf tunai atas dasar Istibsan bi al-'Urfi, sedangkan argumentasi hukum imam al-Zuhri membolehkan wakaf tunai atas dasar kemaslahatan, yaitu dapat dimanfaatkan secara produktif untuk meningkatkan ekonomi. Sebaliknya Imam Syafi'i tidak membolehkan wakaf tunai karena menilai wakaf secara tunai tidak kekal seperti halnya benda wakaf tidak bergerak.

Di Indonesia, secara legalitas formil membenarkan adanya wakaf tunai. Ini terbukti dengan diterbitkannya Undang-Undang 41 Tahun 2004 dan Peraturan Pemerintah Nomor. 42 tahun 2006 tentang Pelaksanaan Undang-Undang Nomor 41 Tahun 2004 sebagai payung hukum perwakafan di Indonesia.Undang-Undang Nomor 41 tahun 2004 Tentang Wakaf, menentukan bahwa benda yang dapat diwakafkan tidak saja benda tetap (tidak bergerak) tetapi terdiri dari benda bergerak dan tidak bergerak. Di antara benda yang bergerak yang dapat diwakafkan adalah wakaf tunai (wakaf uang).

\section{Daftar Pustaka}

Az-Zuhaily, Wahbah, Fiqh al-Islâmî wa Adillatubû, Mesir: Dar al-Fikri, 1986

Azhar Basyir, Ahmad, Hukum Islam Tentang Wakaf, Ijarah dan Syirkah, Bandung: PT. Al-Ma'arif, 1987

Abu Zahrah, Muhammad UshulFiqih, terj. Saefullah Ma'sum, et.al, Jakarta: Pustaka Firdaus, 2005

Ahmed, Habib, Role of Zakah and Awqaf in Poverty Alleviation. Jeddah: IRTI, 2004

Abid Abdullah Al-Kasibi, Muhammad, Hukum Wakaf, Depok: Iman Press,2004

A Karim, Adiwarman, Berderma untuk semua: Wacana dan praktik Filantropi Islam, Jakarta: Teraju, 2003 
Anwar, Syamsul Studi Hukum Islam Kontemporer, (ed.) M. Muchlas Rowie, Jakarta: Rm Books, 2007

Al-Alabij, Adijani, Perwaqapan Tanah di Indonesia. Jakarta: PT. Rajawali Pers, 1989

Biro Perbankan Syari'ah BI 2001, Peranan Perbankan Syari'ah dalam Wakaf Tunai (Sebuah Kajian Konseptual)' dalam WAKAF TUNAI Inovasi Finansial Islam, Jakarta : PSTTI-UI,2006

Daud Ali, Muhammad, Sistem Ekonomi Islam Zakat dan Wakaf, Jakarta: UI Press, 1988

Djunaidi, Achmad dan Thobieb Al-Asyhar, Menuju Era Wakeaf Produktif, Depok : Mumtaz Publishing, 2007

Depag RI, Pedoman Pengelolaan dan Pengembangan Wak.af, Jakarta : Depag RI,2006 -, Undang-Undang Nomor 41 Tahun 2004 Tentang Wakaf dan Peraturan Pemerintah Nomor 42 Tabun 2006 tentang Pelaksanaannya, Jakarta: Direktorat Jenderal Bimbingan Masyarakat Islam, 2007

- Stategi Pengembangan Waqaf Tunai di Indonesia, Jakarta : Direktorat Jendral Bimbingan Masyarakat Islam, 2007

,Paradigma Baru Waqaf di Indonesia, Jakarta : Direktorat Jendral Bimbingan Masyarakat Islam, 2007

Hafidhuddin, Didin, Wakaf Uang Dalam Pandangan Syariat Islam, Kumpulan Hasil Seminar Perwakafan, (Jakarta: Bimas dan Haji DEPAG RI, Jakarta, 2004), h. 194.
Hasanah, Huswatun,Strategi Pengelolaan Wakaf Dalam Meningkatkan Kesejabteraan Umat, Kumpulan Hasil Seminar Perwakafan, Jakarta: Bimas dan Haji DEPAG RI, 2004

L. Esposito, John dalam Ensiklopedi-Oxford Dunia Islam Modern, dan diterjemahkan dari The Oxford Encyclopedia Of the Modern Islamic Word. terj. Eva Y.N. Femmy S., Jarot W., Poerwanto, Rofiq S., Jilisd ke-2, Jakarta: 2001, Mizan

Muzarie, Mukhlisin Fiqh Wakaf, Syarofin Arba MF (ed.), Yogyakarta: Dinamika, 2010

Mannan, Sertifikat Wakaf Tunai, (Depok: Ciber, 2007)

Su'ud Muhammad, Abu, Risalah fi Jawazi Waqf alNuqud, Beirut: Dar Ibnu-Hazm, 1997

Sabiq, Sayyid Fiqih Sunnah, Jakarta: Pena Pundit Aksara, 2007

Sholahuddin, M, Lembaga Ekonomi dan Keuangan Islam, Surakarta: Muhammadiyah University Press, 2006

Zuhdi, Masfuk, Studi Islam dan Muamalah, Jakarta: PT Raja Grafindo Persada, 1993

Zuhri, Muh, Hukum Islam Dalam Lintasan Sejarah, Jakarta: PT. Raja Grafindo Persada,1996

Undang-Undang Nomor 41 Tahun2004 Tentang Wakaf

Peraturan Menteri Agama Nomor 4 Tahun 2009 tentang Administrasi Wakaf Uang.

Keputusan fatwa MUI(tentang wakaf uang) pada tanggal 11 Mei 2002. 